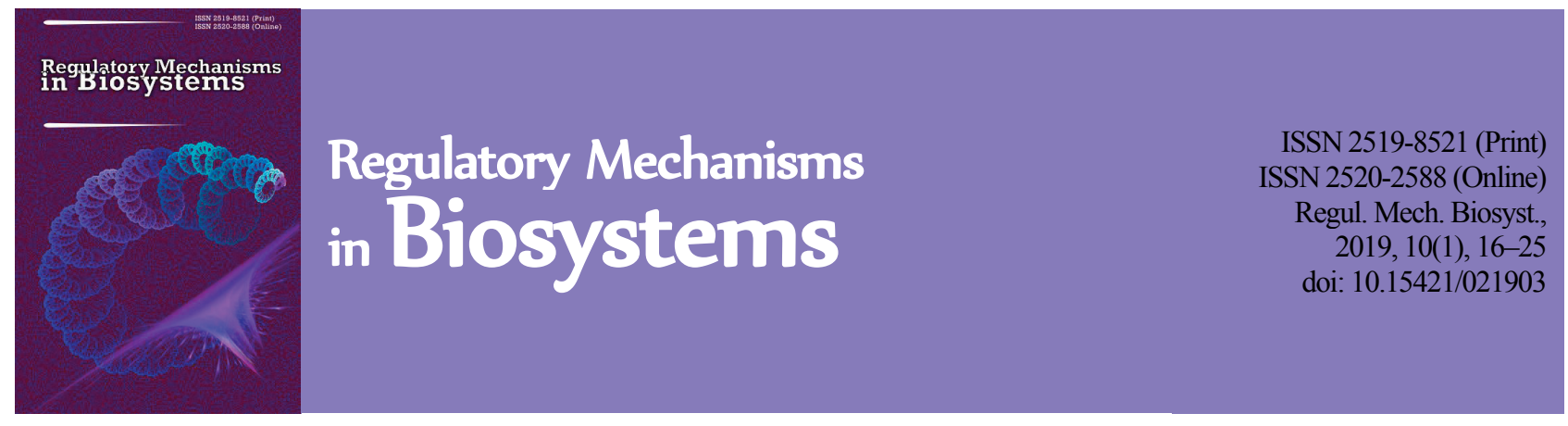

\title{
Effect of drought on photosynthetic apparatus, activity of antioxidant enzymes, and productivity of modern winter wheat varieties
}

\author{
V. V. Morgun, O. O. Stasik, D. A. Kiriziy, O. G. Sokolovska-Sergiienko \\ Institute of Plant Physiology and Genetics NAS of Ukraine, Kyiv, Ukraine
}

Article info

Received 24.01.2019

Received in revised form 26.02.2019

Accepted 28.02.2019

Institute of Plant Physiology and Genetics NAS of Ukraine. Vasylkivska st., 31/17, Kyiv, 03022, Ukraine. Tel.: + 38-067-389-71-65. E-mail:o_stasik@yahoo.com

\begin{abstract}
Morgun, V. V., Stasik, O. O., Kiriziy, D. A., \& Sokolovska-Sergiienko, O. G. (2019). Effect of drought on photosynthetic apparatus, activity of antioxidant enzymes, and productivity of modern winter wheat varieties. Regulatory Mechanisms in Biosystems, 10(1), 16-25. doi:10.15421/021903

The response of modern winter wheat varieties to soil drought was studied with aim of phenotyping their drought tolerance characteristics and identification of the most informative indices that may be suitable for use in breeding programs. Plants of winter bread wheat (Triticum aestivum L.) varieties Podolyanka, Khurtovyna, Vinnychanka and Prydniprovska were grown in a pot experiment. The soil moisture for control plants was maintained at a level of $70 \%$ of field capacity (FC) throughout the vegetative stage. At the flowering, watering of the treated plants was stopped to reduce the soil moisture to a level of $30 \% \mathrm{FC}$ and then this soil moisture level was maintained for 10 days. After that, the irrigation of the treated plants was restored to the level of control. It was found that in the flag leaf under drought condition, the chlorophyll content, net $\mathrm{CO}_{2}$ assimilation rate, and transpiration rate decreased, while the leaf water deficit, the ratio of photorespiration to $\mathrm{CO}_{2}$ assimilation, and the activity of chloroplasts antioxidant enzymes (superoxide dismutase and ascorbate peroxidase) increased. The ten-day drought significantly reduced the grain yield from the plant. Calculations of the relative changes in the physiological parameters of treated plants as compared to the control were the most informative for the differentiation of varieties for drought tolerance. Relative changes in the content of chlorophyll in the flag leaf under drought and reduction in the total biomass of the plant closely correlated with a decrease in grain productivity $(\mathrm{r}=0.92$ and $\mathrm{r}=0.96$ respectively). There was also a significant correlation of grain productivity with a decrease in the NAR measured in the period of drought $(r=0.68)$. Therefore, the maintenance of the photosynthetic function of plants under conditions of insufficient water supply plays a determinant role in reducing the grain productivity losses. The relative changes in the chlorophyll content and $\mathrm{CO}_{2}$ assimilation rate in plants subjected to drought as compared to control may be used as markers of drought tolerance of genotypes for genetic improvement of wheat by conventional breeding and biotechnological methods.
\end{abstract}

Keywords: Triticum aestivum L.; water deficit; photosynthesis; superoxide dismutase; ascorbate peroxidase.

\section{Introduction}

Abiotic and biotic stress factors cause significant losses of crop yield. Experts estimate that these losses can reach up to $80 \%$ of the potential yield under favourable conditions (Sade et al., 2011). Among the natural stress factors, the researchers now are paying attention to drought, which, by classification of land suitable for agricultural use, has the highest frequency of occurrence $-26 \%$. It is especially dangerous that this factor is tending to increase due to global climate changes (Morgun et al., 2010; Lesk et al., 2016). In Ukraine, every 2-3 years drought covers 10-30\%, and every $10-12$ years $-50-70 \%$ of agricultural land (Demyanyuk, 2015).

Various technologies are being developed to prevent the adverse effects of drought on plants, but the breeding of drought tolerant crop varieties is the best way to stabilize yields under poor water conditions (Sadras \& Richards, 2014). Meanwhile it is necessary to know which physiological mechanisms are important for maintaining the production process under water stress conditions in order to improve them through genetic and selection methods. However, work in this direction is complicated by the fact that drought tolerance is a complex trait that characterizes the ability of the plant organism to retain its basic functions in the conditions of a lack of moisture, and in the first place, to maximize the realization of genetic potential of yield (Passioura, 2012). The reaction of plants to drought involves a number of processes on the molecular, cellular, organism, and cenotic levels and depends on the plant's species and variety, the duration and severity of drought, the phase of ontogenetic development, etc. (Pinheiro \& Chaves, 2011). The complexity and multicomponent nature of the plant's reaction to drought causes considerable difficulty in breeding for drought-tolerance. Direct breeding for productivity in conditions of drought is complicated by the polygenic nature of the trait, and as a result - by its low inheritance, epistatic gene interaction, and a high dependence on the interaction of the genotype and environment (Cattivelli et al., 2008). Therefore, in recent years, the study of the possibilities of breeding based on physiological characteristics that determine or closely correlate with productivity in conditions of drought, arouse considerable interest (Lopes et al., 2014).

Proceeding from the general physiological reasons, in terms of these indices the functional state of the photosynthetic apparatus is the most promising, since photosynthesis itself determines the productivity of a plant (Morgun \& Kiriziy, 2012). Numerous experimental data show that photosynthetic indices correlate with the productivity of winter wheat in both optimal and unfavourable growing conditions (Carmo-Silva et al., 2017). The existence of a significant intraspecific variability of wheat plants' photosynthetic apparatus resistance to drought is demonstrated, which reflects the genetically determined ability of the plant organism to adapt and maintain photosynthetic activity under lack of moisture (Gupta et al., 2012; Morgun et al., 2016). Photosynthetic fixation of $\mathrm{CO}_{2}$ and transpiration are processes most sensitive to decline of soil or air moisture, but internal causes for reducing their rate vary 
according to the duration and severity of the drought (Stasik, 2007; Pinheiro \& Chaves, 2011).

After a brief mild drought, the decrease in the $\mathrm{CO}_{2}$ and $\mathrm{H}_{2} \mathrm{O}$ gas exchange rate is dependent on a decrease in the stomata conductivity due to their closure, and is usually not accompanied by damage to the photosynthetic apparatus. Prolonged and severe drought causes significant disruption of photosynthetic metabolism and damage to cellular structures (Lawlor \& Tezara, 2009). Especially dangerous under these conditions is the formation of excessive amounts of reactive oxygen species (ROS) that oxidize proteins, lipids and other biologically important macromolecules, violate their structure and functions, causing the formation of toxic substances. At the same time, the ROS is a key component of the main signaling systems that regulate the response of plants to the action of various stressors, and acclimation to changes in environmental conditions at levels from molecular to organism (Mittler, 2017). Therefore, the antioxidant defense systems are increasingly attracting the attention of researchers. These systems provide effective control of the ROS level in various compartments of plant cells and intercellular space, prevent the damaging effects of free radicals and stabilize the oxidative-reducing balance (Carmody et al., 2016; Caverzan et al., 2016; Ehonen et al., 2018). Especially important is the information on genotypic and in particular intraspecific variability of the functioning of this important part of plants' stress resistance under drought conditions (Singh et al., 2012; Valifard et al., 2012).

Among crops, wheat occupies the most significant place. It is the planet's staple bread crop, grown in almost all areas where farming is possible, and it provides food to the majority of humanity. Therefore, the detection of physiological traits associated with drought tolerance, for use in breeding programs for improving the resistance of wheat plants becomes especially relevant (Morgun et al., 2010).

The aim of our work was to study the response to soil drought of leaves' water regime parameters, content of photosynthetic pigments, gas exchange and transpiration rate, activity of antioxidant protection enzymes and grain productivity in modern winter wheat varieties for their phenotyping on the traits of drought tolerance and identification of the most informative indices that can be suitable for use in breeding programs.

\section{Materials and methods}

The research was conducted on plants of winter bread wheat (Triticum aestivum L.) varieties Podolyanka, Khurtovyna, Vinnychanka and Prydniprovska grown in pots for $10 \mathrm{~kg}$ of fertilized soil under natural light. Each pot contained 15 plants. Fertilizers were added in equal quantities $\left(\mathrm{N}_{80} \mathrm{P}_{80} \mathrm{~K}_{80}+\mathrm{N}_{80} \mathrm{P}_{80} \mathrm{~K}_{80} \mathrm{mg} / \mathrm{kg}\right.$ of soil) when the pots were filled with soil and in the middle of the stalk-shooting phase (BBCH 34).

Prior to flowering, and in the control variant during the entire vegetation, the moisture content of the soil was maintained at a level of $70 \%$ of field capacity (FC). At the flowering, watering of the experimental plants was stopped to reduce the soil moisture to a level of $30 \% \mathrm{FC}$ and then this soil moisture level was maintained for 10 days. The total period of plants growing under reduced water supply was 14 days, covering the phases of flowering and the beginning of milk ripeness. After that, the irrigation of the experimental plants was restored to the control level ( $70 \% \mathrm{FC})$, which was maintained until the end of the vegetation. The humidity of the soil in the pots was controlled gravimetrically twice a day. Determination of water regime indices, photosynthetic pigment content, gas exchange rate and activity of chloroplast antioxidant enzymes of control and experimental plants were carried out at the level of soil moisture content of $30 \% \mathrm{FC}$ (the first day of drought), after seven days of cultivation at $30 \%$ of FC (seventh day of drought) and at the fourth day after the irrigation was renewed to the control level. Elements of the structure of plants' grain productivity were determined after achieving the complete grain maturity by weighing the air-dry material.

Leaf water deficit was determined according to the standard method (Shmatko et al., 1985). To determine the dry weight, the samples were fixed at $105{ }^{\circ} \mathrm{C}$ for $30 \mathrm{~min}$ and dried to a constant weight at $65^{\circ} \mathrm{C}$. The content of chlorophylls $\mathrm{a}$ and $\mathrm{b}$ in the leaves was measured after extraction with dimethyl sulfoxide (DMSO) spectrophotometrically
(Wellburn, 1994). The net assimilation and photorespiration rate were recorded under controlled conditions by an infrared gas analyzer GIAM-5M. The intact flag leaves ( 2 in parallel) were placed in a temperature-controlled $\left(+25^{\circ} \mathrm{C}\right)$ chamber $(3 \times 7 \mathrm{~cm})$ and illuminated $\left(400 \mathrm{~W} / \mathrm{m}^{2}\right.$ PAR) by a KG-2000 incandescent lamp through a water filter to eliminate excess infrared radiation in its spectrum. The air was blown through the chamber at a speed of $11 / \mathrm{min}$. The photorespiration rate was estimated by the postillumination $\mathrm{CO}_{2}$ burst from a leaf for $1 \mathrm{~min}$ after the light was turned off. The transpiration rate was measured by a thermoelectric micropsychrometer based on the difference in air humidity at the inlet and outlet of the chamber.

For the determination of antioxidant enzymes activity, chloroplasts were isolated mechanically at a temperature of $0-4{ }^{\circ} \mathrm{C}$. The average specimen $(2 \mathrm{~g})$ of wheat flag leaves was homogenized in a 7-fold volume of buffer solution of the following composition: $0.33 \mathrm{M}$ sorbitol, $5 \mathrm{mM} \mathrm{MgCl} 2,0.1 \%$ BSA, $4 \mathrm{mM}$ ascorbic acid and $50 \mathrm{mM}$ Tris-HCl ( $\mathrm{pH}$ 7.5). The homogenate was filtered through 2 layers of nylon fabric and centrifuged at a centrifuge K-24D at $80 \mathrm{~g}$ and a temperature of $0-4{ }^{\circ} \mathrm{C}$ for 5 minutes to precipitate heavy particles. The supernatant was poured into other pre-cooled centrifuge tubes and centrifuged at $2000 \mathrm{~g}$ for 10 minutes to obtain a fraction of chloroplasts. The chloroplasts sediment was resuspended in isotonic medium with $4 \mathrm{mM}$ ascorbic acid, $50 \mathrm{mM}$ Tris- $\mathrm{HCl}$ ( $\mathrm{pH} 7.5$ ) in a volume of $2 \mathrm{ml}$ and subsequently used to determine the activity of superoxide dismutase (SOD), and ascorbate peroxidase (APX).

The superoxide dismutase (SOD, EC 1.15.1.1) activity was determined spectrophotometrically using nitrotetrazolium blue at a wavelength of $560 \mathrm{~nm}$ (Giannopolitis \& Ries, 1977). The ascorbate peroxidase (APX, EC 1.11.1.11) activity was measured in the ultraviolet region of the spectrum at $290 \mathrm{~nm}$ using the Chen \& Asada (1989) method. The content of chlorophyll in the chloroplasts suspension was determined by the Arnon (1949) method.

Repeatability of the experiment -5 pots per variant, water deficit determinations 5-fold, analytical repeatability of photosynthetic pigments content determination for the combined sample of leaves of 5 individual plants - 3-fold, determination of gas exchange and enzymes activity 4-fold. Data on components of grain productivity were determined as average of measurements of 20 individual plants. The obtained data were processed by generally accepted methods of variation statistics. The signifycance of the difference between controls and treatments were evaluated using ANOVA. Differences were considered significant at $\mathrm{P}<0.05$.

\section{Results}

Decrease of soil moisture to $30 \%$ of the FC four days after the cessation of watering increased the level of water deficit in the flag leaf by $57.8-69.9 \%$ for the Podolyanka, Khurtovyna, Vinnychanka, and by $141.2 \%$ for Prydniprovska variety (Fig. 1). During a prolonged drought ( 7 days at $30 \%$ FC), the water deficit increased in the flag leaf of the Vinnychanka, Prydniprovska and Khurtovyna varieties. In the treated plants of Podolyanka variety, the level of water deficit remained unchanged throughout the experiment. The greatest increase in water deficit compared with the control was detected in plants of the Vinnychanka variety, and the smallest - in the Podolyanka variety over prolonged drought.

On the fourth day after restoration of watering to the control level, the water deficit in the leaves of treated plants of the Khurtovyna, Vinnychanka and Prydniprovska varieties decreased, although it was $30-40 \%$ higher than that of the control ones. During this period, significant differences between varieties were not detected.

The studied varieties differed significantly in the reaction of the photosynthetic pigment apparatus on soil drought, in particular on the content of chlorophyll (Fig. 2). In the early stages of drought (a decrease in soil moisture up to $30 \%$ FC), a statistically significant decrease in the content of chlorophyll $(16.6 \%)$ was observed only in leaves of the Prydniprovska variety. After seven days of plants growing under low moisture content, a significant decrease in the content of chlorophyll (about 20\%) was found in flag leaves of the Prydniprovska and Vinnychanka varieties, while in the Podolyanka and Khurtovyna varieties it 
was statistically unreliable $(9.6 \%$ and $4.8 \%$ respectively). After restoration of watering to the control level, the content of chlorophyll in the leaves of the treated plants did not increase. The damage to the photosynthetic apparatus caused by drought was retained, the content of chlorophyll in the flag leaves of plants subjected to stress was lower in the Khurtovyna and Podolyanka varieties by 10.4 and $11.8 \%$, respectively, and in the Prydniprovska and Vinnychanka varieties by 20.4 and $22.8 \%$, respecttively, compared to control.

The net assimilation rate (NAR) of the control plants' flag leaves during the period of investigation varied within $25-30 \mathrm{mg} \mathrm{CO}_{2} /\left(\mathrm{dm}^{2}\right.$. h) (Fig. 3). This index was the highest in the Podolyanka, the smallest in the Khurtovina variety. In the treated plants, on the first day of drought, there was a significant decrease in NAR. At this time, in the plants of

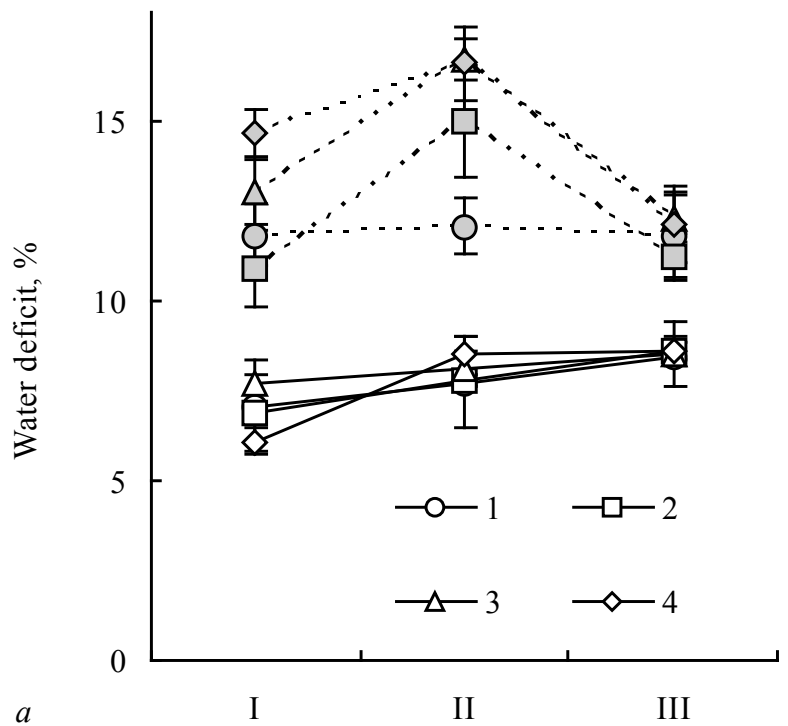

the Podolyanka and Khurtovyna varieties NAR of flag leaves was about $70 \%$ of control, in Vinnychanka - 60.6\%, in Prydniprovska - 26.2\%. Extension of drought to 7 days led to further decrease in NAR in plants of the Podolyanka, Khurtovyna and Vinnychanka varieties to $55.7 \%$, $46.9 \%$ and $40.3 \%$ of control respectively, while in Prydniprovska this index remained at the same level as for the third day.

It is interesting to note that under drought conditions the absolute values of NAR of flag leaves did not differ substantially between the Khurtovyna and Vinnychanka varieties, but calculations in relative terms to control values allowed us to differentiate varieties more clearly according to the reaction of this index to drought (Fig. 3). Four days after the restoration of optimal watering, NAR restored to $85-90 \%$ of the control level in plants of all varieties.

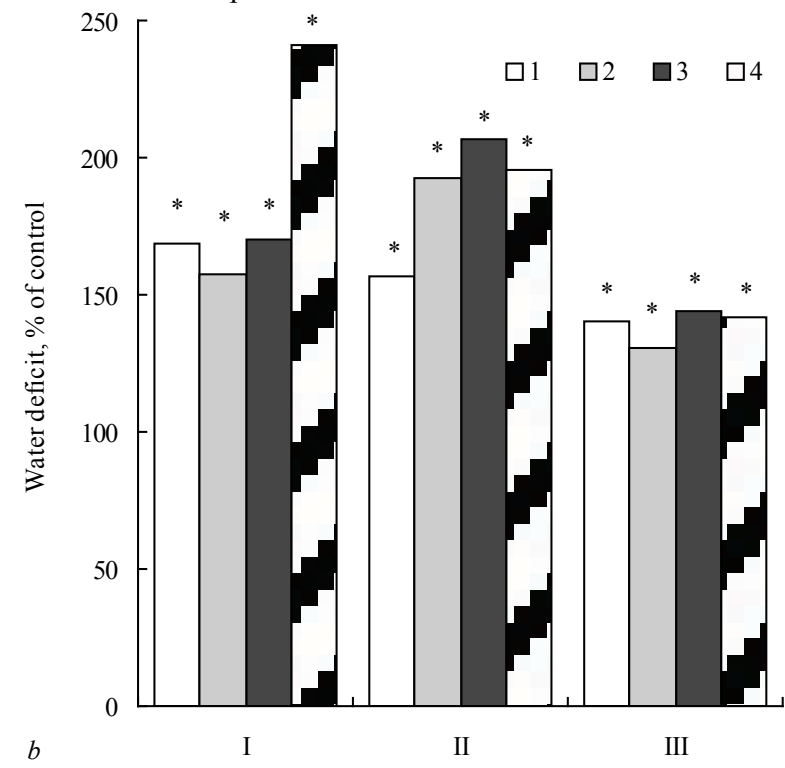

Fig. 1. Effect of soil drought on water deficit in the flag leaf of modern winter wheat varieties $(a)$ and treated variants compared to the control $(b)$ : I - the first day of drought at 30\% field capacity; II - the seventh day of drought at $30 \%$ field capacity; III - the fourth day after the irrigation was restored to the control level (70\% field capacity); varieties: 1 - Podolyanka, 2-Khurtovyna, 3 - Vinnychanka, 4-Prydniprovska; solid lines - control, dotted-treatment; data points represent the mean values $\pm \mathrm{SE}, \mathrm{n}=5 ;{ }^{*}$ - significant difference compared to the control, $\mathrm{P}<0.05$
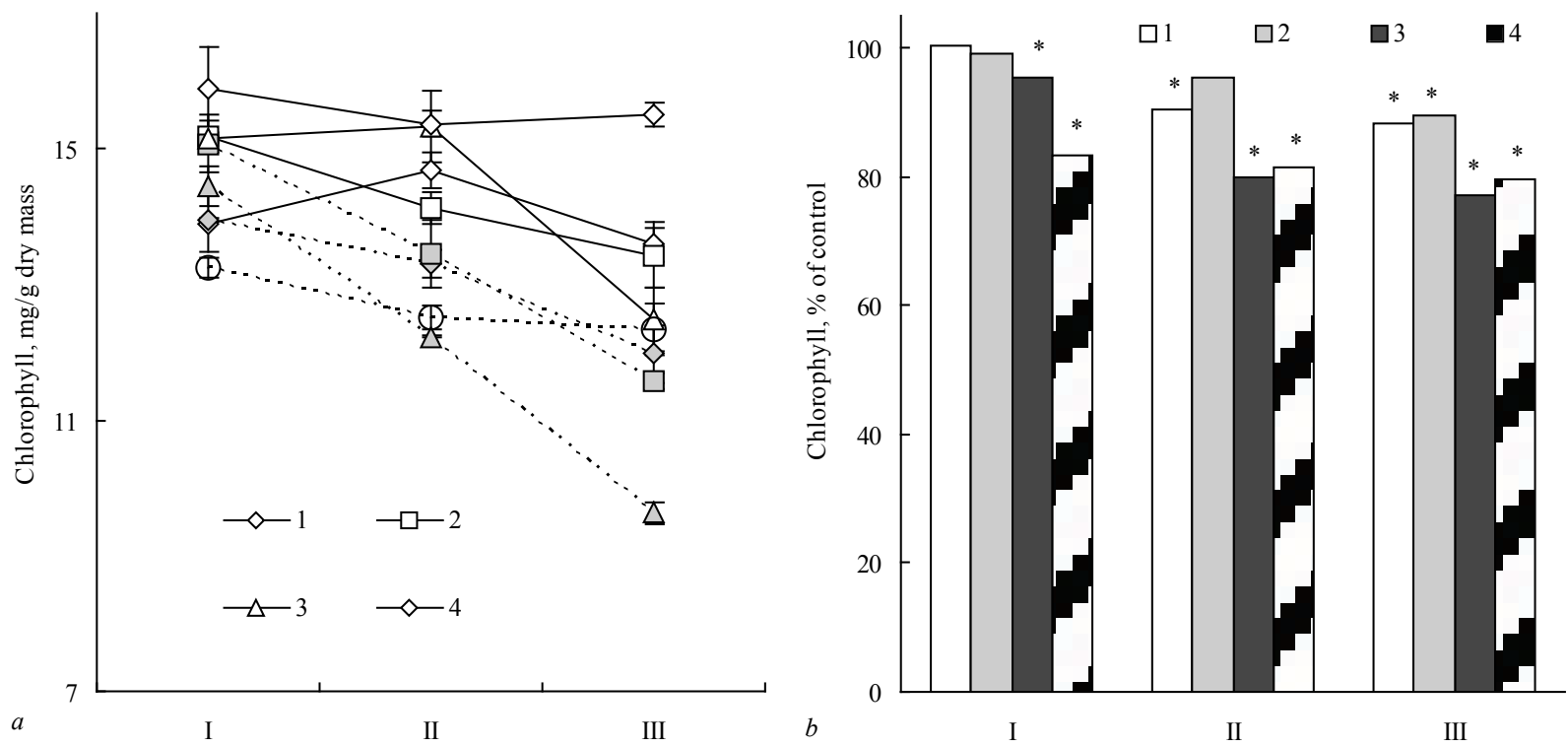

Fig. 2. Effect of soil drought on the total chlorophyll content in the flag leaf of modern winter wheat varieties $(a)$ and treated variants compared to the control $(b): \mathrm{n}=3$; see Fig. 1

According to the leaf transpiration rate, control plants differed slightly (Fig. 4). One can only note the general tendency to decrease of this index at the end of the observation period in plants of all varieties, except Prydniprovska. Already on the first day of drought, the transpiration rate of all plant varieties greatly decreased (more than twice), with the difference between varieties practically equalized. At the same time, on the seventh day of drought there was a clear intervarietal differentiation according to this index. In the Podolyanka variety, the intensity of transpiration even 
slightly increased compared to the first day of drought, although it was still much lower than the control. In the leaves of the Khurtovyna variety, the extension of water stress duration practically did not change the transpiration value compared to that observed at the beginning of drought. In plants of the Vinnychanka and Prydniprovska varieties on the seventh day of drought, the leaves' transpiration rate significantly decreased compared with the value of this index for the first day.

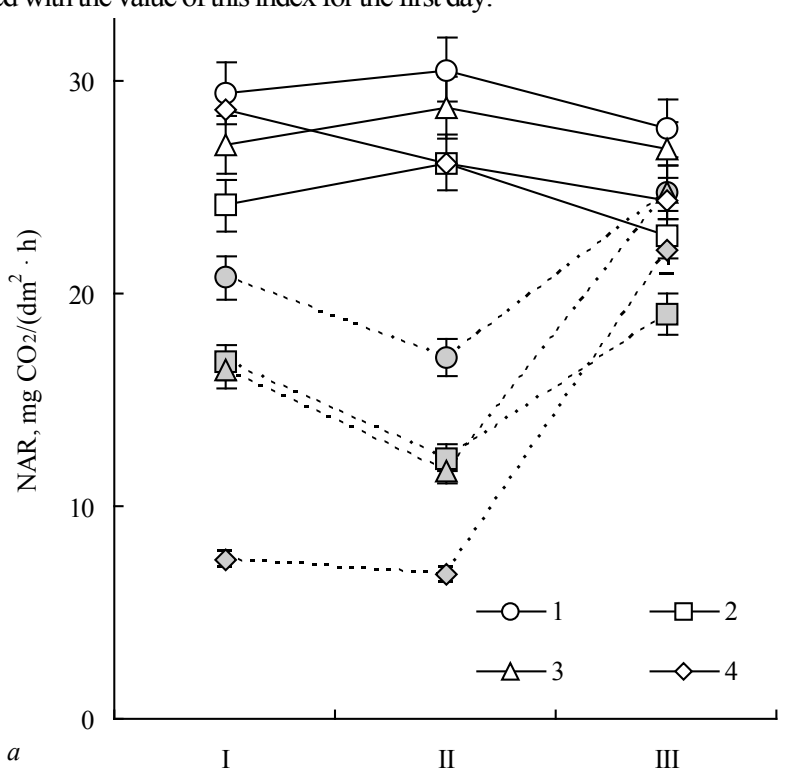

In relative terms, compared with the control values, the transpiration rate on the first day of drought in the Podolyanka and Khurtovyna varieties was $38.8 \%$ and $40.7 \%$ of control, respectively, and in the Vinnychanka and Prydniprovska varieties $43.1 \%$ and $47.2 \%$, respectively (Fig. 4). It should be noted that this small difference between varieties was more due to differences in transpiration between control plants.

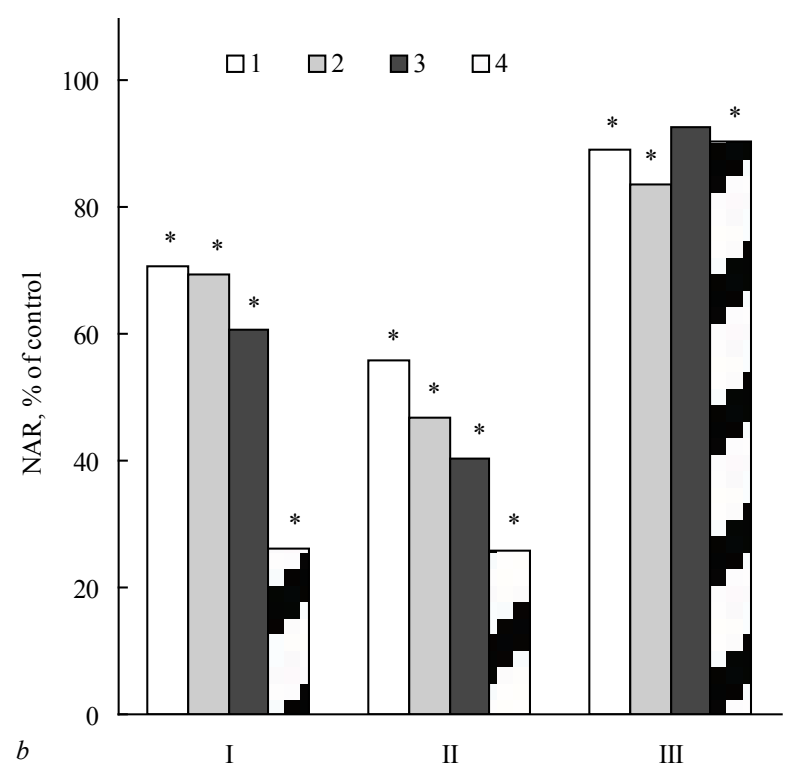

Fig. 3. Effect of soil drought on the net assimilation rate (NAR) in the flag leaf of modern winter wheat varieties $(a)$ and treated variants compared to the control $(b): \mathrm{n}=4$; see Fig. 1
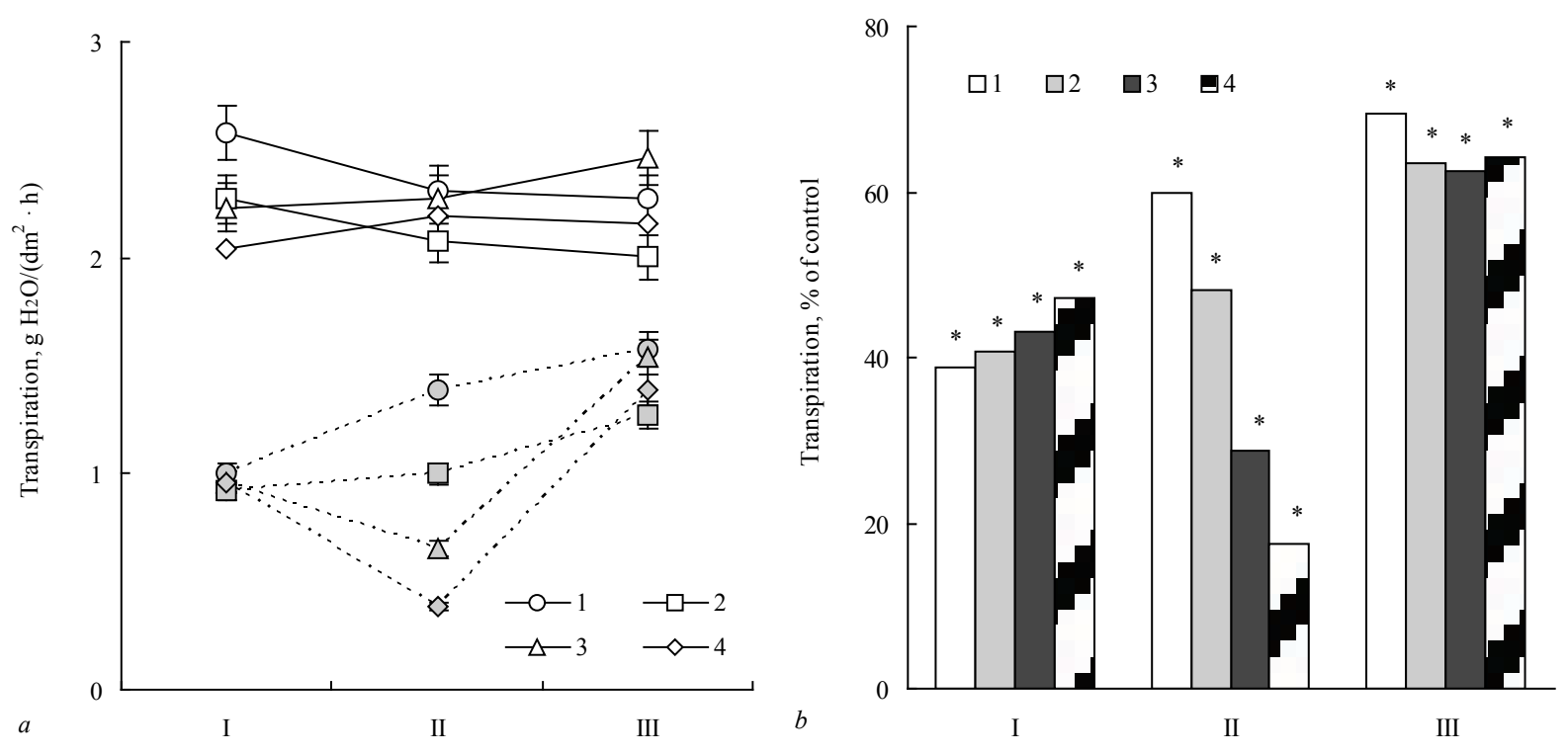

Fig. 4. Effect of soil drought on the transpiration rate in the flag leaf of modern winter wheat varieties $(a)$ and treated variants compared to the control $(b): \mathrm{n}=4$; see Fig. 1

On the seventh day of drought, on the contrary, a clear intervarietal differentiation on the relative values of transpiration occurred due to the difference in the dynamics of this index with the water stress prolongation. Therefore, the indices obtained in this period more objectively reflect the response of the studied varieties to soil drought. In the Podolyanka variety, the intensity of transpiration in this period was $60.0 \%$ of control, Khurtovyna $-48.1 \%$, Vinnychanka - $28.8 \%$, Prydniprovska - only $17.5 \%$. It should be noted that these results correlate well with the above-presented data on the leaves' water deficit with which the transpiration was in inverse relationship $(\mathrm{r}=-0.79)$. With the restoration of watering, the transpiration rate of treated plants increased, although within a week it did not reach the control values. It was $69.5 \%$ in the Podolyanka variety, in the Khurtovyna, Vinnychanka and Prydniprovska varieties - only $62.5-64.3 \%$ of control.
In contrast to photosynthesis and transpiration, the photorespiration rate of plant leaves on the first day of drought in the Podolyanka, Khurtovyna and Vinnychanka varieties was higher than control (Fig. 5). Only in Prydniprovska did this index decrease to $65.3 \%$ of control. On the seventh day of drought, in Podolyanka plants the photorespiration rate exceeded control by almost $9.5 \%$, the Vinnychanka variety was at the control level, and the Khurtovyna and Prydniprovska varieties were lower than control (90.5 and $71.3 \%$ of control, respectively). After restoration of watering, photorespiration of plant leaves of the Podolyanka and Khurtovyna varieties was about $90 \%$ of control, and in the Vinnychanka and Prydniprovska varieties it exceeded control value by $9.7-15.4 \%$. When comparing the response to drought of the photosynthetic apparatus of wheat plants of various genotypes, one can proceed from the fact that an increase of photorespiration rate when the photosynthetic rate 
remains at a relatively higher level is evidence of its positive protective role. In the first place, this was typical for the Podolyanka and, to a lesser extent, for Khurtovyna and Vinnychanka varieties. Additional information on this subject gives estimation of the dynamics of photorespiration to photosynthesis ratio.
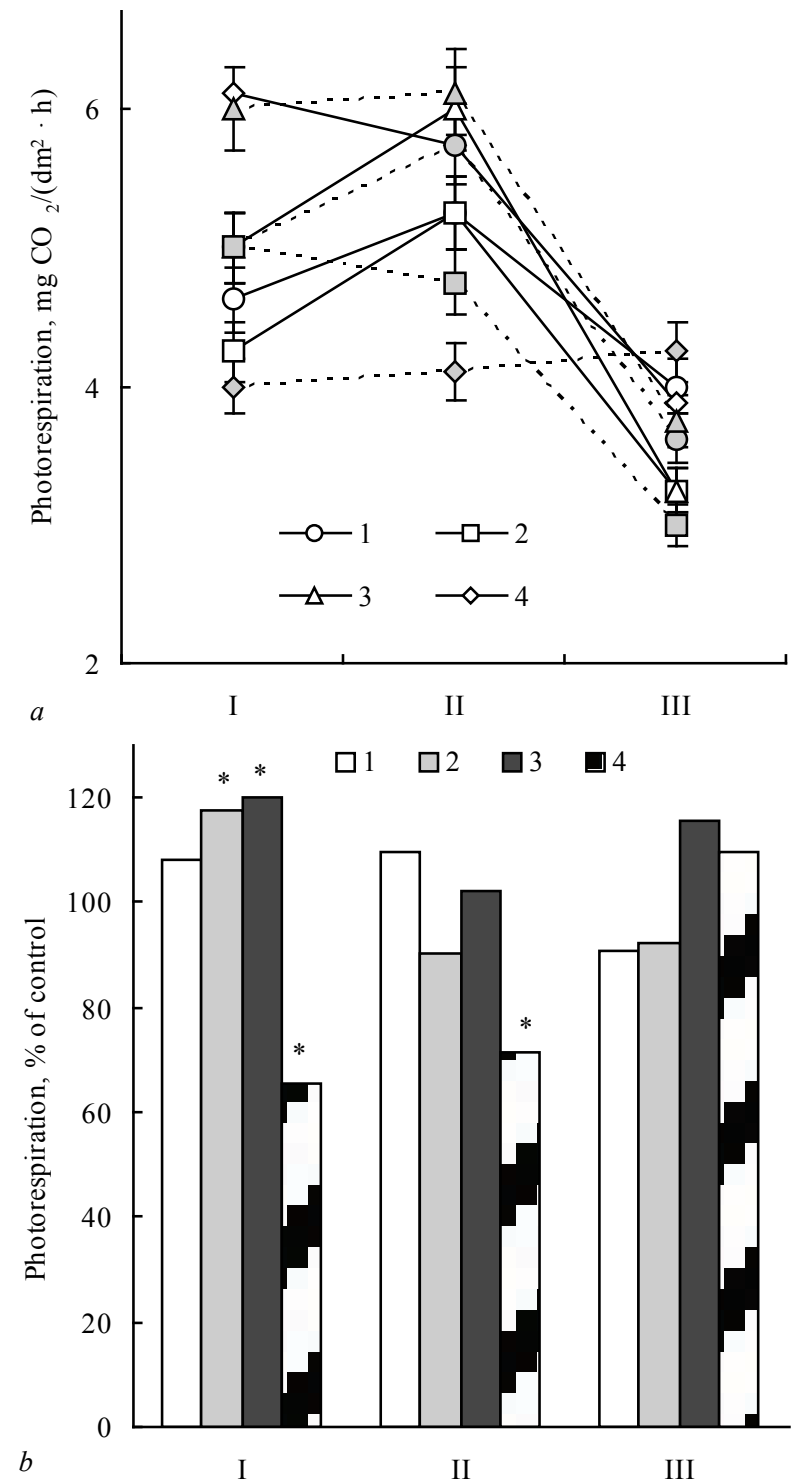

Fig. 5. Effect of soil drought on the photorespiration rate in the flag leaf of modern winter wheat varieties $(a)$ and treated variants compared to the control $(b): n=4$; see Fig. 1

Photorespiration/photosynthesis ratio of leaves of plants subjected to drought increased several times (Fig. 6). This was due to the difference in the photosynthesis and photorespiration dynamics. The increase in this ratio was mainly due to a decrease in the photosynthetic rate under drought, but changes in photorespiration also had some influence, which made the difference between the varieties more clear than in the case of photosynthesis alone. Thus, the treated plants of the Vinnychanka and Khurtovyna varieties, as already mentioned, practically did not differ in absolute values of NAR under drought conditions (Fig. 3), but the ratio of photorespiration/photosynthesis of the first variety was significantly higher than that of the second one.

The Prydniprovska variety had the highest value of the photorespiration/photosynthesis ratio of flag leaf under drought conditions and the lowest one was in the Podolyanka variety. With the prolongation of drought, there was a tendency to increase of this index in plants of all varieties, that is, the proportion of photorespiration in the carbon dioxide exchange of leaves increased. After restoration of watering, the ratio of photorespiration to the photosynthesis of the treated plants' leaves returned practically to the control values. In the plants which all the time were under optimal watering conditions the differences in the photorespiration/photosynthesis ratio were insignificant, and in general, this index was quite stable with a weak tendency to decrease at the end of the observation period (Fig. 6).

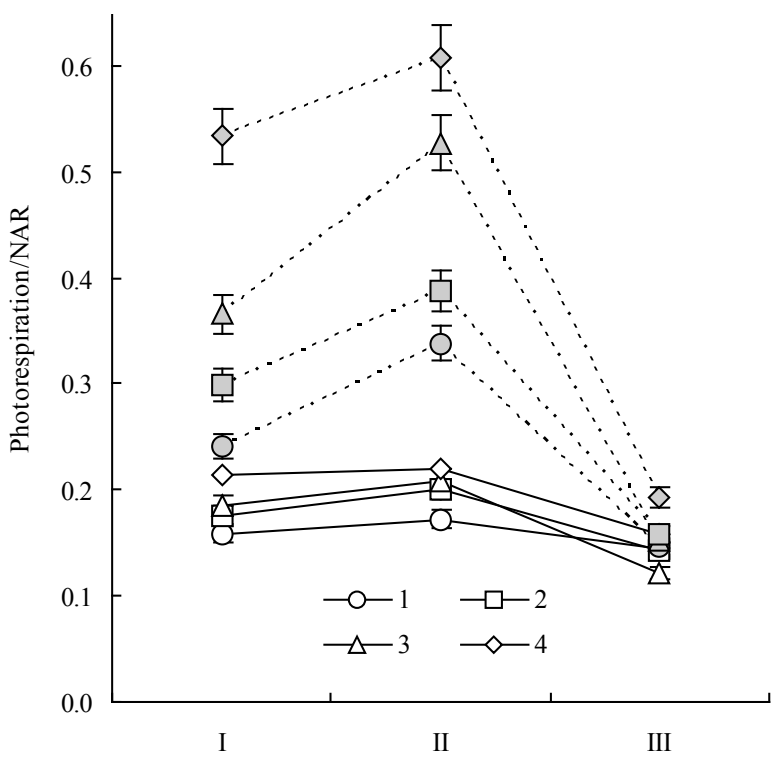

Fig. 6. Effect of soil drought on the photorespiration $/$ net $\mathrm{CO}_{2}$ assimilation ratio in the flag leaf of modern winter wheat varieties: $\mathrm{n}=4$; see Fig. 1

An important component of the photosynthetic apparatus protection under stressful conditions is the active functioning of the ROS neutralizing systems, in particular enzymes. We found that the activity of the two main chloroplast antioxidant enzymes - SOD and APX - as a rule, significantly increased under the action of drought (Fig. 7, 8). Only in plants of the Prydniprovska variety did SOD activity tend to decrease. The activity of this enzyme in the chloroplasts of the Podolyanka variety leaves on the first day of drought practically did not change compared with control, but on the seventh day it exceeded control by $36.0 \%$ (Fig. 7). On the fourth day after the restoration of normal watering of the treated plants, this index returned almost to the control value. In plants of the Khurtovyna variety, on the first day of drought, there was a tendency to increase the activity of chloroplastic SOD, and on the seventh day it exceeded control by $33.7 \%$. After watering, this index decreased almost to the control value. The greatest increase in the SOD activity under drought conditions was observed in plants of the Vinnychanka variety on the first (by $29.9 \%$ compared to the control), and on the seventh day (by $61.0 \%$ ). Even a week after restoration of watering, this index in the treated plants exceeded the control value by $17.3 \%$.

The dynamics of APX activity in chloroplasts of flag leaves of plants subjected to drought slightly differed from such SOD (Fig. 8). Already on the first day of drought, the activity of APX significantly increased in plants of all varieties, with the strongest in Podolyanka and Prydniprovska (respectively $65.4 \%$ and $86.4 \%$ ). In the plants of the Khurtovyna and Vinnychanka varieties, on the first day of drought, the activity of APX also increased, albeit to a lesser extent (31.1 and 49.7\% respectively) than in the other two varieties (we recall that the activity of SOD demonstrated the opposite response). On the seventh day of drought, in these two varieties APX activity remained at almost the same level as control, in the Podolyanka and Prydniprovska varieties it continued to increase and more than doubled the control indices. On the fourth day of the restoration of watering, the activity of chloroplastic APX of the leaves of plants of all varieties returned to control values.

Ultimately, the 14-day soil drought in the flowering phase significantly reduced the grain productivity of the main shoots and the whole plant of the studied winter wheat varieties (Table 1,2). The weight of grain from one plant of the Khurtovyna variety decreased in comparison with the control by $12.6 \%$, Podolyanka - by $16.1 \%$, Prydniprovska - by $22.8 \%$, and Vinnychanka - by $33.1 \%$. 

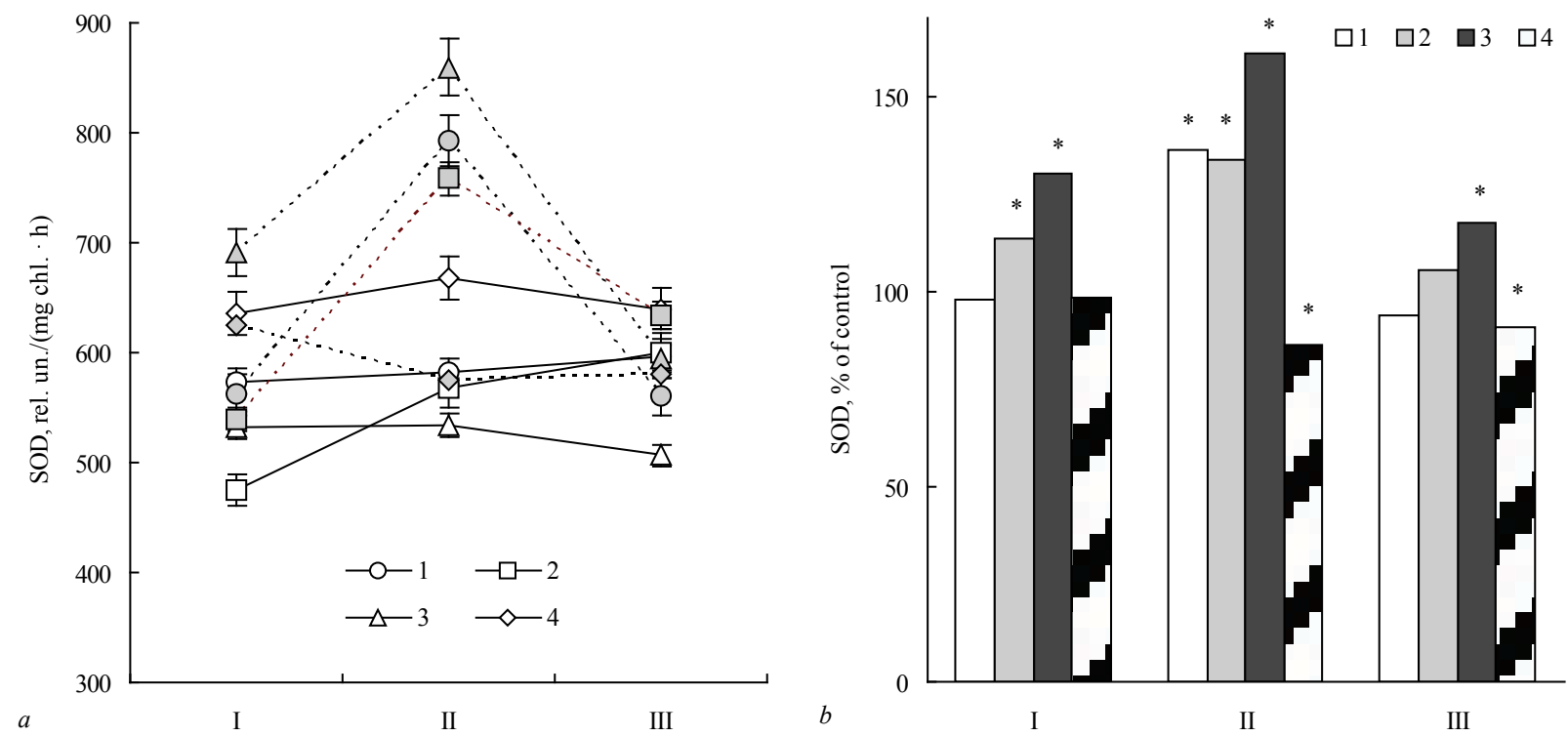

Fig. 7. The effect of soil drought on the activity of superoxide dismutase (SOD) in chloroplasts of the flag leaf of modern winter wheat varieties (a) and treated variants compared to the control $(b): \mathrm{n}=4$; see Fig. 1
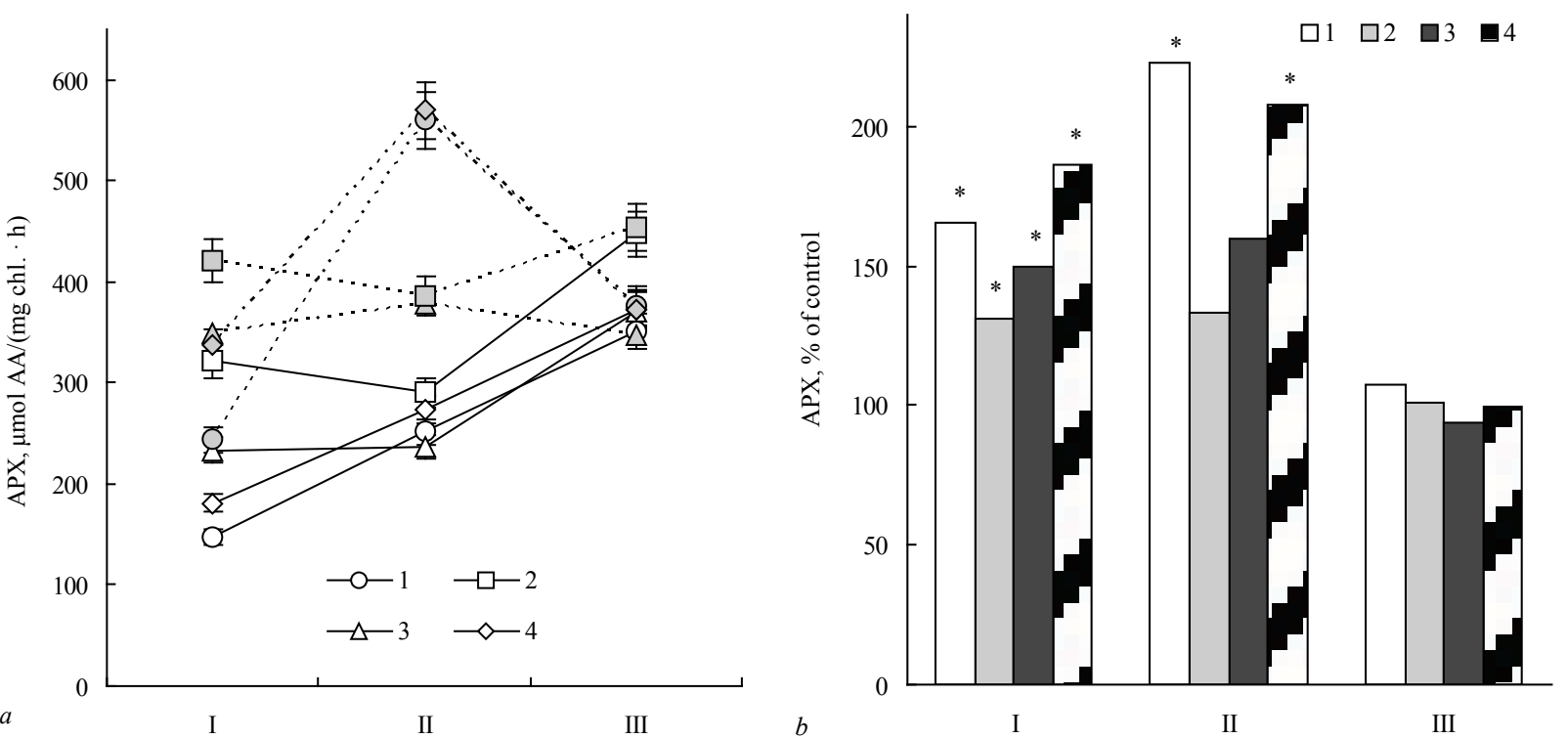

Fig. 8. Effect of soil drought on the activity of ascorbate peroxidase (APX) in chloroplasts of the flag leaf of modern winter wheat varieties $(a)$ and treated variants compared to the control $(b): \mathrm{n}=4$; see Fig. 1

Table 1

Effect of drought on the components of the main shoot productivity of modern winter wheat varieties $(x \pm S E ; n=20)$

\begin{tabular}{llcccccc}
\hline Variety & \multicolumn{1}{c}{ Variant } & Shoot mass, $\mathrm{g}$ & $\begin{array}{c}\text { Stem mass } \\
\text { including leaves, } \mathrm{g}\end{array}$ & Grain mass, $\mathrm{g}$ & Grain number & 1000 grains mass, $\mathrm{g}$ & $\begin{array}{c}\text { Grain mass/ } \\
\text { stem mass ratio }\end{array}$ \\
\hline \multirow{3}{*}{ Podolyanka } & control & $4.39 \pm 0.13$ & $2.04 \pm 0.09$ & $1.97 \pm 0.07$ & $40.7 \pm 1.5$ & $48.3 \pm 0.9$ & $0.96 \pm 0.05$ \\
& treatment & $3.98 \pm 0.19$ & $1.67 \pm 0.09$ & $1.88 \pm 0.10$ & $36.7 \pm 1.1$ & $50.8 \pm 1.5$ & $1.12 \pm 0.04$ \\
& \% of control & 90.7 & $82.1^{*}$ & 95.5 & $90.2^{*}$ & 105.1 & $116.4^{*}$ \\
\hline \multirow{3}{*}{ Khurtovyna } & control & $4.07 \pm 0.13$ & $1.33 \pm 0.05$ & $2.23 \pm 0.08$ & $57.0 \pm 1.5$ & $39.1 \pm 0.8$ & $1.68 \pm 0.06$ \\
& treatment & $3.75 \pm 0.15$ & $1.26 \pm 0.05$ & $1.94 \pm 0.10$ & $52.4 \pm 2.1$ & $36.9 \pm 1.0$ & $1.54 \pm 0.05$ \\
& \% of control & 92.1 & 94.6 & $86.9^{*}$ & $91.8^{*}$ & $94.5^{*}$ & $91.9^{*}$ \\
\hline \multirow{3}{*}{ Vinnychanka } & control & $4.60 \pm 0.17$ & $1.87 \pm 0.10$ & $2.29 \pm 0.09$ & $48.1 \pm 1.8$ & $47.8 \pm 1.2$ & $1.22 \pm 0.05$ \\
& treatment & $3.96 \pm 0.13$ & $1.53 \pm 0.05$ & $2.00 \pm 0.09$ & $39.5 \pm 2.0$ & $51.4 \pm 1.3$ & $1.31 \pm 0.04$ \\
& \% of control & $86.1^{*}$ & $82.2^{*}$ & $87.7^{*}$ & $82.1^{*}$ & $107.5^{*}$ & $106.7^{*}$ \\
\hline \multirow{3}{*}{ Prydniprovska } & control & $3.89 \pm 0.08$ & $1.31 \pm 0.03$ & $2.23 \pm 0.08$ & $49.6 \pm 2.1$ & $45.3 \pm 1.5$ & $1.71 \pm 0.03$ \\
& treatment & $3.77 \pm 0.10$ & $1.21 \pm 0.07$ & $2.14 \pm 0.09$ & $44.7 \pm 2.7$ & $47.8 \pm 1.9$ & $1.77 \pm 0.05$ \\
& \% of control & 97.0 & 92.7 & 95.8 & $90.1^{*}$ & 105.6 & 103.4 \\
\hline
\end{tabular}

Note: $*$ - significant difference compared to the control $(\mathrm{P}<0.05)$. 
Table 2

Effect of drought on the components of the whole plant productivity of modern winter wheat varieties $(x \pm S E ; n=5)$

\begin{tabular}{|c|c|c|c|c|c|c|c|c|}
\hline Variety & Variant & $\begin{array}{l}\text { Total above-ground } \\
\text { plant mass, } g\end{array}$ & Grain mass, $\mathrm{g}$ & Grain number & $\begin{array}{l}1000 \text { grains } \\
\text { mass, } g\end{array}$ & Harvest index & $\begin{array}{c}\text { Total stem } \\
\text { number }\end{array}$ & $\begin{array}{c}\text { Productive shoots } \\
\text { number }\end{array}$ \\
\hline \multirow{3}{*}{ Podolyanka } & control & $10.90 \pm 0.49$ & $4.78 \pm 0.24$ & $109.0 \pm 5.2$ & $44.0 \pm 0.8$ & $0.44 \pm 0.01$ & $3.06 \pm 0.11$ & $3.06 \pm 0.11$ \\
\hline & treatment & $8.94 \pm 0.53$ & $4.01 \pm 0.28$ & $85.6 \pm 5.2$ & $46.6 \pm 1.4$ & $0.44 \pm 0.01$ & $3.00 \pm 0.16$ & $2.80 \pm 0.15$ \\
\hline & $\%$ of control & $82.1^{*}$ & $83.9^{*}$ & $78.5^{*}$ & 106.1 & 101.1 & 98.2 & 91.6 \\
\hline \multirow{3}{*}{ Khurtovyna } & control & $7.66 \pm 0.51$ & $4.07 \pm 0.28$ & $110.6 \pm 7.0$ & $36.9 \pm 0.9$ & $0.53 \pm 0.01$ & $2.70 \pm 0.18$ & $2.65 \pm 0.17$ \\
\hline & treatment & $7.06 \pm 0.40$ & $3.56 \pm 0.22$ & $101.7 \pm 6.6$ & $35.3 \pm 0.9$ & $0.50 \pm 0.01$ & $2.67 \pm 0.16$ & $2.57 \pm 0.18$ \\
\hline & $\%$ of control & 92.1 & 87.4 & 92.0 & 95.7 & $94.5^{*}$ & 98.9 & 97.0 \\
\hline \multirow{3}{*}{ Vinnychanka } & control & $8.72 \pm 0.68$ & $4.30 \pm 0.31$ & $102.3 \pm 7.2$ & $42.4 \pm 1.1$ & $0.50 \pm 0.01$ & $2.43 \pm 0.16$ & $2.43 \pm 0.16$ \\
\hline & treatment & $5.96 \pm 0.33$ & $2.88 \pm 0.19$ & $58.2 \pm 4.6$ & $50.9 \pm 1.3$ & $0.48 \pm 0.01$ & $2.05 \pm 0.15$ & $1.75 \pm 0.14$ \\
\hline & $\%$ of control & $68.3^{*}$ & $66.9^{*}$ & $56.9^{*}$ & $120.1^{*}$ & 96.5 & $84.2^{*}$ & $71.9^{*}$ \\
\hline \multirow{3}{*}{ Prydniprovska } & control & $9.57 \pm 0.49$ & $5.05 \pm 0.25$ & $125.5 \pm 7.5$ & $40.8 \pm 0.8$ & $0.53 \pm 0.01$ & $3.11 \pm 0.19$ & $3.11 \pm 0.19$ \\
\hline & treatment & $7.34 \pm 0.43$ & $3.90 \pm 0.24$ & $82.5 \pm 5.7$ & $48.0 \pm 1.2$ & $0.53 \pm 0.01$ & $2.77 \pm 0.13$ & $2.32 \pm 0.14$ \\
\hline & $\%$ of control & $76.7^{*}$ & $77.2^{*}$ & $65.8^{*}$ & $117.5^{*}$ & 100.2 & 89.3 & $74.7^{*}$ \\
\hline
\end{tabular}

Note: see Table 1.

\section{Discussion}

The results of determining the water deficit of leaves provide grounds for arguing that Prydniprovska variety plants have a poor ability to adapt quickly to the sharp increase of water shortage in the soil, as evidenced by the significantly greater increase of water deficit in the leaves of this variety in the early stages of the drought development, compared to the other investigated varieties (Fig. 1). Apparently, in Prydniprovska variety plants, stomatal regulation is more inertial, which leads to the preservation of stomata openness with deterioration of moisture conditions. Such a feature of the reaction increases the risk of significant violations under prolonged rise in drought.

At the same time, the stability of water deficit in treated plants of the Podolyanka variety is an evidence of high plasticity and the ability to regulate water regime in unfavourable conditions of water supply. The further growth of water deficit in the leaves was partly due to a decrease in the air humidity, which is confirmed by some increase in it also in plants of the control variant.

Drought, especially prolonged, significantly influenced the assimilation activity of plants, reducing the chlorophyll content, $\mathrm{CO}_{2}$ assimilation rate and transpiration of leaves. At the same time there was a differentiation of plants by the degree of reduction of these indices, especially in the calculation as compared with control values. In order of reduction, the studied varieties can be arranged in the following way: Podolyanka $>$ Khurtovyna $>$ Vinnychanka $>$ Prydniprovska. Decrease of transpiration rate under drought conditions is, on the one hand, a positive phenomenon, since it contributes to reducing the water losses of the plant and maintaining the watering of cells. However, on the other hand, the closure of stomata alone leads to inhibition of $\mathrm{CO}_{2}$ assimilation processes, substrate and energy depletion in cells, increases photodamage of protein structures of photosystems and as a consequence results in secondary oxidative stress and subsequent destruction of photosynthetic apparatus, which significantly inhibits the restoration of its normal functioning after the cessation of drought and exacerbates its negative impact on grain productivity (Stasik, 2007).

Maintenance of leaves' transpiration during a long period at relatively high level in arid conditions indicates the ability of the plant root system to absorb water from the soil even at low humidity. It can be provided as a morphological (the area of the root active surface), and physiological (water absorbing power, water potential in the root hairs cells) peculiarities of plants of a specific genotype.

Based on these considerations, the best response of plant leaves' transpiration to drought was demonstrated by the Podolyanka variety, followed by the decrease in drought-tolerance of the Khurtovyna, Vinnychanka and Prydniprovska varieties.

In contrast to photosynthesis and transpiration, the photorespiration rate of plant leaves under drought conditions exceeded control values, or its decrease was significantly lower than that observed for photosynthesis. It is well known in the literature that photorespiration under stress conditions can play a protective role in the photosynthetic apparatus as an alternative electron acceptor of the photosynthetic electron transport chain (ETC) and as the $\mathrm{CO}_{2}$ donor within the leaf (Stasik, 2014; Hanawa et al., 2017). This is especially important under drought, when stomata are closed to reduce water loss, but $\mathrm{CO}_{2}$ assimilation is inhibited due to decreased stomatal conductivity. This lowers the use of reducing and energy equivalents in the Calvin cycle, and leads to superreduction of the ETC components, which in turn increases the risk of photodestruction of its structures (Neto et al., 2017). Therefore, photorespiration, reducing the ETC "tension" and supplying $\mathrm{CO}_{2}$ in the leaf, supports the functional state of the photosynthetic apparatus under stress conditions and protects it from damage. At the same time, the "reverse side" of photorespiration is the production of ROS, in the first place - hydrogen peroxide. Because of this, the effectiveness of its protective function depends largely on the rate of ROS neutralization, that is, the activity of antioxidant cell defense systems. Only with their high activity does photorespiration play a positive protective role (Bai et al., 2017). Otherwise, increased photorespiration under drought conditions without proper ROS detoxification can increase the damage to cellular structures.

It is known that the main enzymes of chloroplasts' antioxidant protection - SOD and APX - function as sequential components of the ROS detoxification system. SOD catalyzes the superoxide radicals' dismutation in $\mathrm{H}_{2} \mathrm{O}_{2}$ and $\mathrm{O}_{2}$, APX detoxifies hydrogen peroxide through its oxidation reaction with ascorbic acid. One of the ways to form a superoxide radical anion is the transfer of electrons to oxygen from chloroplast ETC (Mehler's reaction). This reaction is intensified under stress conditions when the use of ETC products (ATP and NADPH) in the dark reactions of $\mathrm{CO}_{2}$ assimilation in the Calvin cycle is inhibited. In particular, such a phenomenon takes place in the light under drought conditions, when the flow of $\mathrm{CO}_{2}$ into mesophyll cells is limited by the closure of stomata. As a result, the ETC components are converted to a superreductional state, which intensifies electron transfer to oxygen. Superoxide radical anion is a very aggressive ROS that oxidizes proteins and other macromolecules of the photosynthetic apparatus, which leads to their destruction.

Excessive hydrogen peroxide is also a rather dangerous ROS, but it is always present in a cell in a given amount, as it is a product of many biochemical reactions. It has now been proved that $\mathrm{H}_{2} \mathrm{O}_{2}$ in the "physiological" concentration can act as a messenger in the cell signaling network, and a rapid increase in its content triggers a cascade of stressprotective reactions (Kolupaev \& Karpets, 2014; Ehonen et al., 2018). In a photosynthetic cell, such an increase may occur, in particular, as a result of asynchronous changes in the SOD and APX activity under unstable environmental conditions, including the effects of such a stress factor as drought. So, if, during a certain period of time, SOD activity will increase to a greater extent than APX activity, it will increase the formation of hydrogen peroxide in chloroplasts, which can be perceived by the cell as a signal of transition to a stressful state. A quantitative index that allows us to estimate the probability of such a course of events is the ratio of SOD/APX activity, measured simultaneously. If it increases, you can expect an increase in $\mathrm{H}_{2} \mathrm{O}_{2}$ content, and vice versa - the relative increase in activity of APX should reduce the concentration of this ROS.

From this perspective, we analyzed the obtained data on changes of chloroplasts' antioxidant enzymes activity in the flag leaves under drought conditions. A certain intraspecific difference in magnitude and dynamics 
of the SOD/APX ratio to both control and treated plants was found (Fig. 9). In the leaves of the Podolyanka and Prydniprovska varieties, this index in control variants was markedly higher in all terms of observation compared to Khurtovyna and Vinnychanka. However, in the first two varieties drought led to a much stronger decrease of the SOD/APX ratio as compared to control than in the second pair. It was typical of both the first and the seventh day of drought. The restoration of irrigation of treated plants promoted the return of the SOD/APX ratio to the control values. It should be noted that in plants of the Podolyanka and Prydniprovska varieties, the decrease in the SOD/APX ratio on the first day of drought was caused by a sharp increase in the activity of the APX, whereas in the Khurtovyna and Vinnychanka varieties activity of both enzymes was changed synchronously. On the seventh day of drought, in plants of the Podolyanka variety the activity of SOD increased, but to a lesser extent than APX (36.0\% and $122.7 \%$, respectively, as compared to control), which led to a decrease in their ratio. In plants of the Prydniprovska variety, the SOD activity during this period even decreased slightly (by $13.9 \%$ relative to control) against the background of a strong increase in APX activity (by 108.0\%), which was reflected in the smallest value of their ratio for the entire period of observations.
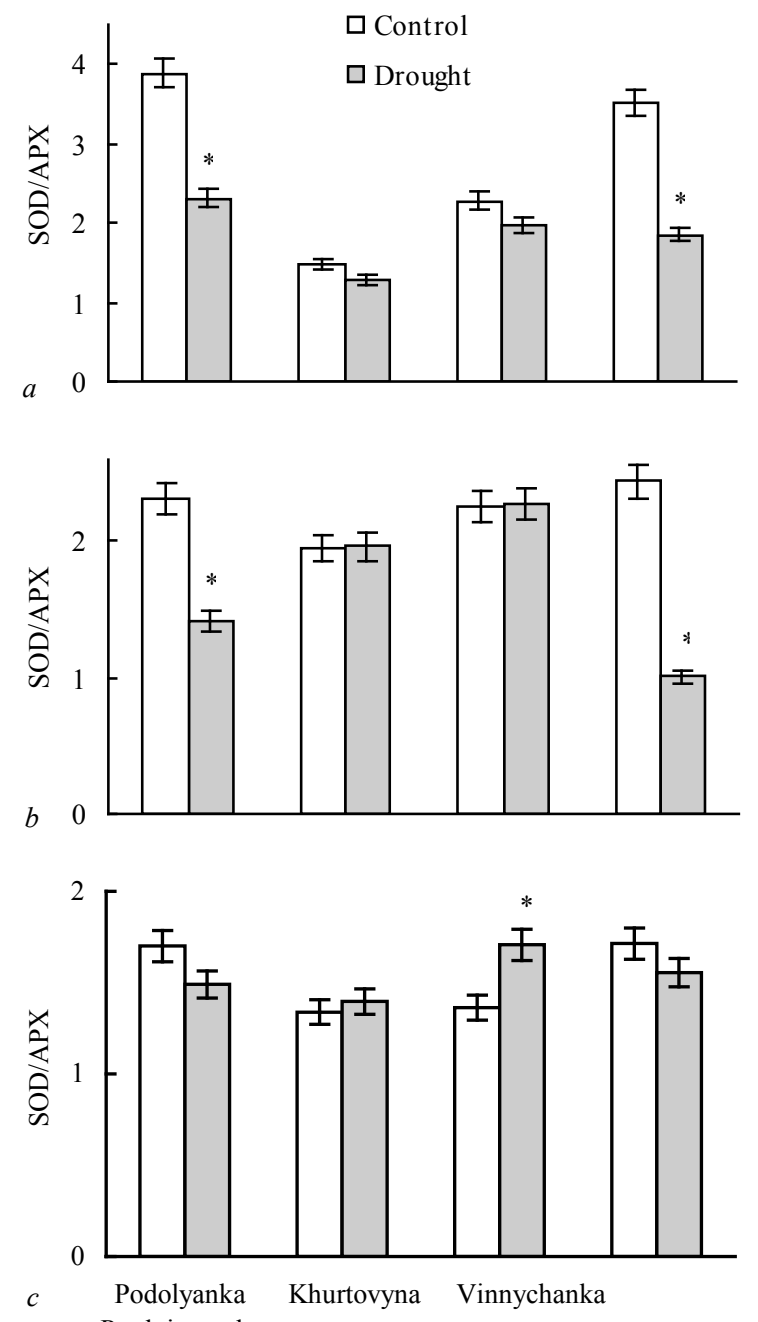

Fig. 9. Effect of soil drought on the ratio of superoxide dismutase (SOD) to ascorbate peroxidase (APX) activities in chloroplasts of flag leaf of different wheat varieties: $a$ - the first day of drought at $30 \%$ field capacity; $b$ - the seventh day of drought at $30 \%$ field capacity; $c$ - the fourth day after the irrigation was restored to the control level $(70 \%$ field capacity); data points represent the mean values $\pm S E, n=4$;

$*$ - significant difference compared to the control $(\mathrm{P}<0.05)$

Thus, the chloroplast antioxidant system of the flag leaves of the Podolyanka and Prydniprovska wheat varieties in the beginning of drought reacted mainly by increasing the activity of APX, without significant changes in SOD. This may be due to relatively high values of SOD activi- ty in these varieties under normal conditions (Fig. 7). It can be assumed that with the onset of drought, this high activity was accompanied by intense formation of hydrogen peroxide, which the APX responded to. However, in Podolyanka, on the seventh day of drought, SOD activity increased with an even greater increase in APX activity. This ensured a reliable protection of the photosynthetic apparatus both from the superoxide radical anion and from $\mathrm{H}_{2} \mathrm{O}_{2}$. At the same time, in plants of the Prydniprovska variety SOD did not respond to drought, and the main role in ROS detoxification was played by the APX. This is probably due to the highest ratio of photorespiration, which is the source of $\mathrm{H}_{2} \mathrm{O}_{2}$, to photosynthesis under drought conditions (Fig. 6). In plants of the Khurtovyna and Vinnychanka varieties these chloroplast antioxidant protection enzymes functioned in a more balanced way.

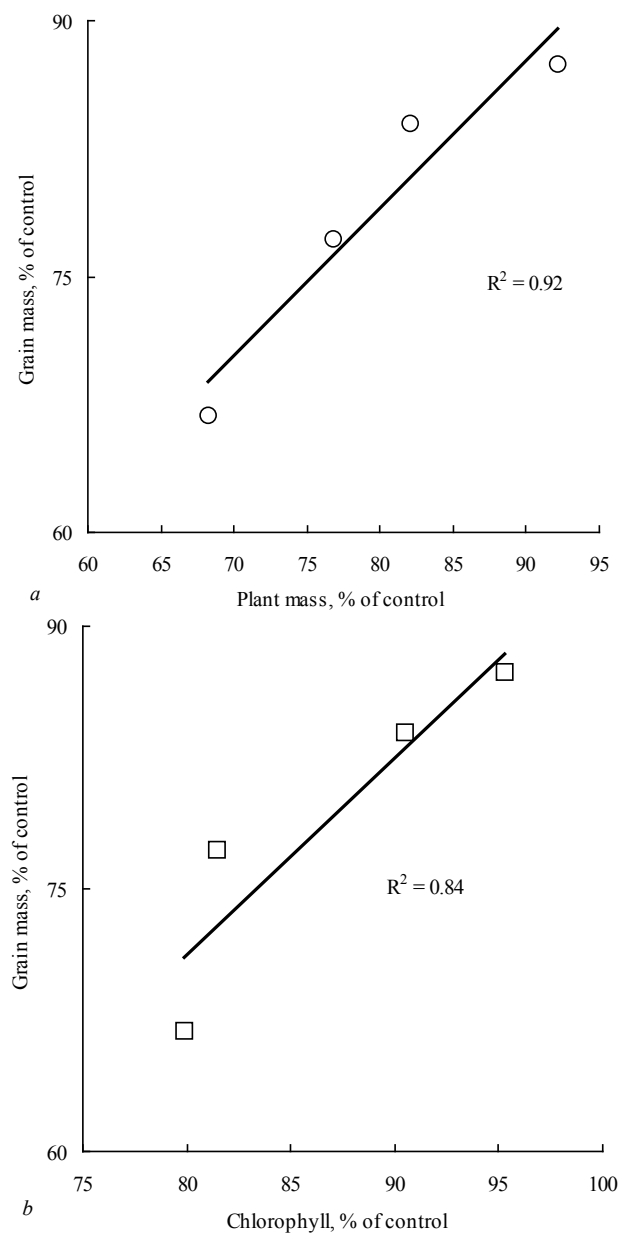

Fig. 10. Relationship between the relative changes in the total aboveground mass of the wheat plants $(a)$, the content of chlorophyll in the flag leaf $(b)$, and the changes in the grain yield of the plants subjected to soil drought

Based on the analysis of the dynamics of chloroplasts SOD and APX activity in wheat flag leaves, it can be concluded that in plants of the Podolyanka variety these components of the antioxidant system are most effective. Thus, on the first day of drought, the ratio of SOD/APX activity in Podolyanka was the highest among all studied varieties, which indirectly indicates an increase in the formation of hydrogen peroxide, which can act as a signal of stress state. On the seventh day of drought, the strongest increase in the activity of APX was observed in this variety, and significant - SOD,which confirms the activation of antioxidant protection systems of the photosynthetic apparatus. In plants of the Prydniprovska variety, the APX activity also significantly increased, but SOD practically did not respond to drought, which is a sign of certain defects of the signaling system regarding the launch of protective mechanisms under the stressor influence. It will be recalled that in plants of this variety the photosynthetic rate under drought conditions was the lowest (Fig. 3). The chloroplast antioxidant system of the Khurtovyna and Vinnychanka varieties adequately responded to drought by synchronous increa- 
se in the SOD and APX activity, but additional regulatory stress signal due to the increased generation of hydrogen peroxide in them, apparently, was less pronounced than in Podolyanka. These data agree with the results of photosynthetic rate and chlorophyll content measurements in the leaves, and thoroughly characterize the ability of the photosynthetic apparatus to adapt to the drought conditions for different wheat varieties.

Photosynthesis, without a doubt, is a determining component of the production process, but the required criterion for assessing the drought tolerance of the variety is the grain yield of the plants subjected to the action of the stressor. Analysis of the grain productivity components revealed that the most important factors of its reduction in treated plants were the reduction of biomass accumulation and grain quantity in the ear. The coefficient of correlation of changes in relation to the control of the grain mass with changes in the total plant weight was $0.96(\mathrm{P}<0.01)$ (Fig. 10a), with the number of grains $-0.95(\mathrm{P}<0.01)$. At the same time, the grain weight from the whole plant slightly negatively correlated with a weight of 1000 grains $(r=-0.32)(\mathrm{NS})$, which, in turn, correlated negatively with the number of grains $(\mathrm{r}=-0.76)(\mathrm{P}<0.05)$.

The obtained results indicate that the main cause for the decrease in grain productivity was the inhibition of the photosynthetic function, since the accumulation of total biomass of plants decreased. Changes in the chlorophyll content in the flag leaf after 7 days of drought correlated with changes in the grain weight from the plant with a coefficient of $0.92(\mathrm{P}<0.01)$ (Fig. 10b). Similar results for the positive correlation of chlorophyll content with grain yield under stressful conditions of drought and high temperature were recently obtained in 15 varieties of durum wheat (Barutcular et al., 2017). The authors of this work suggest this physiological index as a breeding criterion for assessing the stress tolerance of genotypes.

As the plants were subjected to drought in the flowering phase, so deterioration in the supply of assimilates reduced the grain number on plants. At the same time, due to the smaller number of grains on treated plants, competition for assimilates between grains during their formation decreased when the water supply of plants was at the control level, which resulted in a negative correlation between the weight of 1000 grains and their number. To a certain extent, the decrease in number of grains could also be conditioned by the direct influence of drought on the development of generative organs (Distelfeld et al., 2014).

It should be noted that the correlation between the relative decrease in the photosynthetic rate during the drought period and changes in the mass of grain from the plant was also significant $(\mathrm{r}=0.68)$, but to a lesser extent than that of chlorophyll content. This can be explained by the increase in treated plants of remobilisation of plastic substances accumulated earlier in vegetative organs, first of all in the stem, during the grain filling, as is discussed in the literature (Ji et al., 2010). The data we have obtained also indicate that drought significantly altered the distribution of biomass (assimilates) in the plant. Thus the reduction of total biomass and the grain mass of the whole plant was greater than that of the main shoot (Table 1,2), indicating the priority of its supply with assimilates compared with lateral shoots in the conditions of deterioration of the plant photosynthetic function. In addition, in the studied varieties, except for the Khurtovyna variety, drought reduced the grain mass from the main shoot less than the mass of stems and leaves. At the same time, the ratio of grain and stem mass increased (Table 1). Consequently, due to the shortage of assimilates, caused by drought, the plastic substances from the stem were more actively remobilized to fill the grain. This property was more pronounced in the plants of the Podolyanka variety, which were characterized by a higher height and mass of the stem compared with the Khurtovyna and Prydniprovska varieties. Taking into account the results of the biomass redistribution within the plant under the influence of drought, it should be considered that the productivity of the whole plant more correctly characterizes the reaction of the variety to the stress factor in the pot experiment.

\section{Conclusions}

The essential variability of the response to soil drought of modern winter wheat varieties - Podolyanka, Khurtovyna, Vinnychanka and Prydniprovska - was determined based on the indices of the leaves' water regime, state of photosynthetic apparatus, antioxidant enzymes activity, and grain productivity. Under the influence of drought, water deficit of leaves increased, chlorophyll content, photosynthetic and transpiration rate decreased, while the part of photorespiration in the $\mathrm{CO}_{2}$ exchange in the light and the chloroplast antioxidant enzymes activity increased. The ten-day drought at $30 \% \mathrm{FC}$ in the period of flowering - beginning of milk ripeness significantly reduced the grain yield per plant.

Calculations of the relative changes in the physiological parameters of the treated plants as compared to the control values for each variety were the most informative for the differentiation of varieties for drought tolerance. Thus, relative changes in the chlorophyll content in flag leaf under the effect of drought and the reduction of plants' total biomass closely correlated with a decrease in grain productivity. The correlation of the last index with the decrease in the photosynthetic rate, measured during the period of drought, was also significant, but less tight, as the plants subjected to drought intensified the processes of remobilization of assimilates accumulated in the stem earlier in the period of vegetative growth.

Consequently, maintenance of the plants' photosynthetic function under limited water supply due to minimizing the damage to leaf water regime, maintaining leaf chlorophyll content and photosynthesis rate and owing to increase in the antioxidant enzymes activity, plays a key role in reduction of grain productivity losses. Relative changes in these physiological parameters, in particular, the chlorophyll content and photosynthetic rate, in plants subjected to drought, correlate closely with grain yield, and can serve as specific drought tolerance markers which could be used for obtaining new, more drought tolerant winter wheat varieties by conventional breeding or biotechnology methods.

\section{References}

Arnon, D. I. (1949). Copper enzyme in isolated chloroplasts. Polyphenolooxidase in Beta vulgaris. Plant Physiology, 24(1), 1-15.

Bai, J., Kang, T., Wu, H. D., Lu, B. Y., Long, X. G., Luo, X. J., Zhang, Y. Y., Zhou, Y. L., \& Gong, C. M. (2017). Relative contribution of photorespiration and antioxidative mechanisms in Caragana korshinskii under drought conditions across the Loess Plateau. Functional Plant Biology, 44(11), 1111-1123.

Barutcular, C., El Sabagh, A., Koc, M., \& Ratnasekera, D. (2017). Relationships between grain yield and physiological traits of durum wheat varieties under drought and high temperature stress in mediterranean environments. Fresenius Environmental Bulletin, 26(6), 4282-4291.

Carmody, M., Waszczak, C., Idänheimo, N., Saarinen, T., \& Kangasjärvi, J. (2016). ROS signalling in a destabilised world: A molecular understanding of climate change. Journal of Plant Physiology, 203(1), 69-83.

Carmo-Silva, E., Andralojc, P. J., Scales, J. C., Driever, S. M., Mead, A., Lawson, T., Raines, C. A., \& Parry, M. A. J. (2017). Phenotyping of field-grown wheat in the UK highlights contribution of light response of photosynthesis and flag leaf longevity to grain yield. Journal of Experimental Botany, 68(13), 3473-3486.

Cattivelli, L., Rizza, F., Badeck, F.-W., Mazzucotelli, E., Mastrangelo, A. M., Francia, E., Mare, C., Tondelli, A., \& Stanca, A. M. (2008). Drought tolerance improvement in crop plants: An integrated view from breeding to genomics. Field Crops Research, 105(1), 1-14.

Caverzan, A., Casassola, A., \& Brammer, S. P. (2016). Antioxidant responses of wheat plants under stress. Genetics and Molecular Biology, 39(1), 1-6.

Chen, G.-X., \& Asada, K. (1989). Ascorbate peroxidase in tea leaves: Occurrence of two isozymes and the differences in their and molecular properties. Plant and Cell Physiology, 30(7), 987-998.

Demyanyuk, O. S. (2015). Prodovol'cha bezpeka Ukrainy v kontekstí zmín klímatu [Food safety of Ukraine in the context of climate change]. Agroecological Journal, 4, 14-21 (in Ukrainian).

Distelfeld, A., Avni, R., \& Fischer, A. M. (2014). Senescence, nutrient remobilizetion, and yield in wheat and barley. Journal of Experimental Botany, 65(14), 3783-3798

Ehonen, S., Yarmolinsky, D., Kollist, H., \& Kangasjarvi, J. (2018). Reactive oxygen species, photosynthesis, and environment in the regulation of stomata. Antioxidants and Redox Signaling, in print.

Giannopolitis, C. N., \& Ries, S. K. (1977). Superoxide dismutase. Occurrence in higher plants. Plant Physiology, 59(2), 309-314.

Gupta, P. K., Balyan, H. S., Gahlaut, V., \& Kulwal, P. L. (2012). Phenotyping, genetic dissection, and breeding for drought and heat tolerance in common wheat: Status and prospects. Plant Breeding Reviews, 36, 85-168.

Hanawa, H., Ishizaki, K., Nohira, K., Takagi, D., Shimakawa, G., Sejima, T., Shaku, K., Makino, A., \& Miyake, C. (2017). Land plants drive photorespiration as higher electron-sink: Comparative study of post-illumination transient $\mathrm{O}_{2}$ - 
uptake rates from liverworts to angiosperms through ferns and gymnosperms. Physiologia Plantarum, 161(1), 138-149.

Ji, X. M., Shiran, B., Wan, J. L., Lewis, D. C., Jenkins, C. L. D., Condon, A. G., Richards, R. A., \& Dolferus, R. (2010). Importance of pre-anthesis anther sink strength for maintenance of grain number during reproductive stage water stress in wheat. Plant, Cell and Environment, 33(6), 926-942.

Kolupaev, Y. E., \& Karpets, Y. V. (2014). Aktivnyye formy kisloroda i stressovyy signaling u rasteniy [Active oxygen forms and stress signaling in plants]. Ukrainian Biochemical Journal, 86(4), 18-35 (in Russian).

Lawlor, D. W., \& Tezara, W. (2009). Causes of decreased photosynthetic rate and metabolic capacity in water-deficient leaf cells: A critical evaluation of mechanisms and integration of processes. Annals of Botany, 103(4), 561-579.

Lesk, C., Rowhani, P., Ramankutty, N. (2016). Influence of extreme weather disasters on global crop production. Nature, 529(7584), 84-87.

Lopes, M. S., Rebetzke, G. J., \& Reynolds, M. (2014). Integration of phenotyping and genetic platforms for a better understanding of wheat performance under drought. Journal of Experimental Botany, 65(21), 6167-6177.

Mittler, R. (2017). ROS are good. Trends in Plant Sciences, 22(1), 11-19.

Morgun, V. V., \& Kiriziy, D. A. (2012). Perspektyvy i suchasni strategii polipshennya fiziologichnykh oznak pshenitsy dlia pidvyschennya ii produktyvnosti [Prospects and modern strategies of wheat physiological traits improvement for increasing productivity]. Physiology and Biochemistry of Cultivated Plants, 44(6), 463-483 (in Ukrainian).

Morgun, V. V., Kiriziy, D. A., \& Shadchina, T. M. (2010). Ekofiziologicheskiye i geneticheskiye aspekty adaptatsii kul'turnykh rasteniy $\mathrm{k}$ global'nym izmeneniyam klimata [Ecophysiological and genetic aspects of adaptation of cultivated plants to global climate changes]. Physiology and Biochemistry of Cultivated Plants, 42(1), 3-22 (in Russian).

Morgun, V. V., Stasik, O. O., Kiriziy, D. A., \& Pryadkina, G. O. (2016). Zvyazok reaktsiyi fotosyntetychnykh pokaznykiv i zernovoyi produktyvnosti na gruntovu posukhu v kontrastnykh za stiykistyu sortiv ozymoyi pshenytsi [Relations between reactions of photosynthetic traits and grain productivity on soil drought in winter wheat varieties contrasting in their tolerance]. Plant Physiology and Genetics, 48(5), 371-381 (in Ukrainian).

Neto, M. C. L., Silveira, J. A. G., Cerqueira, J. V. A., \& Cunha, J. R. (2017). Regulation of the photosynthetic electron transport and specific photoprotective mechanisms in Ricinus communis under drought and recovery. Acta Physiologiae Plantarum, 39(8), 183.

Passioura, J. B. (2012). Phenotyping for drought tolerance in grain crops: When it is useful to breeders? Functional Plant Biology, 39(11), 851-859.

Pinheiro, C., \& Chaves, M. M. (2011). Photosynthesis and drought: Can we make metabolic connections from available data? Journal of Experimental Botany, 62(3), 869-882.

Sade, B., Soylu, S., \& Yetim, E. (2011). Drought and oxidative stress. African Journal of Biotechnology, 10(54), 11102-11109.

Sadras, V. O., \& Richards, R. A. (2014). Improvement of crop yield in dry environments: Benchmarks, levels of organization and the role of nitrogen. Journal of Experimental Botany, 65(8), 1981-1995.

Shmatko, I. G., Grigoryuk, I. A., Shvedova, O. E., \& Petrenko, N. I. (1985). Opredeleniye fiziologicheskoy reaktsii zernovykh kul'tur na ukhudsheniye vodoobespechennosti i povysheniye temperatury [Determination of the physiological reaction of cereals to deterioration of water availability and temperature increase]. IPPG, Kiev (in Russian).

Singh, S., Gupta, A. K., \& Kaur, N. (2012). Differential responses of antioxidative defence system to long-term field drought in wheat (Triticum aestivum L.) genotypes differing in drought tolerance. Journal of Agronomy and Crop Science, 98(3), 185-195.

Stasik, O. O. (2014). Fotodykhaniye: Metabolizm i fiziologicheskaya rol' [Photorespiration: Metabolism and the physiological role]. In: Allahverdiev, S. I., Rubin, A. B., \& Shuvalov, V. A. (Eds.). Modern photosynthetic problems. Institute for Computer Research, Moskow, Izhevsk. Vol. 2. Pp. 505-535 (in Russian).

Stasik, O. O. (2007). Reaktsiya fotosyntetychnogo aparatu $C_{3}$ roslyn na vodnyi defitsit [The response of photosynthetic apparatus of $\mathrm{C}_{3}$ plants to water deficits]. Physiology and Biochemistry of Cultivated Plants, 39(1), 14-27 (in Ukrainian).

Valifard, M., Moradshahi, A., \& Kholdebarin, B. (2012). Biochemical and physiological responses of two wheat (Triticum aestivum $\mathrm{L}$.) cultivars to drought stress applied at seedling stage. Journal of Agricultural Science and Technology, 14(S), 1567-1578.

Wellburn, A. R. (1994). The spectral determination of chlorophylls $a$ and $b$, as well as total carotenoids, using various solvents with spectrophotometers of different resolution. Plant Physiology, 144, 307-313. 